\title{
Examining Women Discrimination: By Women in Kashmir
}

\author{
Aafreen Manzoor \\ Department of Law, Central University of Kashmir, Ganderbal, India \\ Email address: \\ Aafreenmanzoor26@gmail.com
}

\section{To cite this article:}

Aafreen Manzoor. Examining Women Discrimination: By Women in Kashmir. International and Public Affairs. Vol. 5, No. 1, 2021 , pp. 7-10. doi: $10.11648 /$ j.ipa.20210501.12

Received: March 18, 2021; Accepted: March 30, 2021; Published: April 20, 2021

\begin{abstract}
Women constitute 3.82 billion in the world (According to the UN Population Division). Women being a constant contributory to the economic factor are still considered to be anonymous to the world. Women play a significant role in our lives, from being daughter to a mother. Women help to shape the lives of people in an enormous number of ways. Kashmiri women have been prone to many changes throughout their lives. It leaves a great impact on the Kashmiri Society. Women have been discriminated by the same sex since ages but no concern has been raised for the issue till now. It needs to be controlled and curtailed so that it won't affect the growth of women in our societies. The objective behind the paper is to aware the people of the discrimination happening in our surroundings and to reach to the point where people will be able to raise a voice against it especially women of our society that are being victimized throughout their lives. This paper mainly lays stress on the discrimination against women by women in Kashmir. The paper starts with the introduction to the concept to discrimination with respect to women and includes the instances that are based on research work in Kashmir. The study has been carried out in different regions of Kashmir. In this study, survey method has been used for the collection of the data. The result of the research is not satisfying but enriched with the instances of discrimination. In conclusion, many factors were responsible for the growth of such behavior in our society.
\end{abstract}

Keywords: Women, Discrimination, Society, Development, Kashmir

\section{Introduction to the Concept "Women Discrimination"}

"I do not wish them [women] to have power over men; but over themselves."

---- Mary Wollstonecraft, A Vindication of the Rights of Women (1792).

The women are being discriminated from time immemorial in our country. Discrimination, defined by the Merriam Webster is "the practice of unfairly treating a person or group of people differently from other people or groups of people". [1] Many efforts have been made in the Indian society to uplift the gender equality of women. Nonetheless, there are certain hindrances in protecting the rights of women. Further, many legislations were being made by the government in order to protect the interests of the women in society. [2]

Although many laws were enacted towards the gender equality, but widening gap is still prevalent in the society. The World Economic Forum (WEF, 2017) in their report states, gender inequality continues to be a gruesome problem that is widening day by day rather than overcoming the previous results. [3] The purpose for fighting against women discrimination is to keep human rights in pace. It is existential for human rights of all beings. International human rights bars sex discrimination and ensure civil, political, economic, cultural and social rights of all men and women equally. CEDAW under Article 15 (1) supports the same principle.[4] This Article provides the research questions including name, age, residence, family details and the description of the problem which the person has faced or gone through.

Catherine Nichols is a writer from Boston; she has narrated her side of the story of discrimination. She sent her novel to 50 females and got 2 positive replies only. Then she sent the same novel to 50 females nut under a male name, she got 17 replies. It was clear to see the difference. She received more criticism under the name of female and more praises under the name of male. [5] Thus, discrimination needs to be operated on, which means we need to recognize the bias and the impact it had on the women at first place. This can be hard on us but we can decide how to respond. Since social 
change is not an overnight process, it requires constant awareness and nerve to change the system. [6]

\section{Historical Perspective of "Women Discrimination"}

Human Rights have gained universal acceptance throughout the world and respect for them is considered to be an existential element of a civilized society. Human Rights include various dimensions and can be related to liberty, security, equality, and free from all notions of discriminations. The inclusion of women in human rights came to be by a gradual process in the society. [7] There exist many processes and perspectives from which the discrimination arises. Social Comparison theory is one such perspective. It means people compare themselves to other people and that's when they consider themselves better or worse than others. It creates a sense of discrimination and thus provides roots to the process of discrimination. [8]

The process of women discrimination to empowerment has been described under various heads:

Women in Vedic Period: During the Vedic Period, patriarchy was declined and was replaced to matriarchy. It was said that women in this period enjoyed high status in the society. In the Rig Vedic period, women enjoyed intellectual and spiritual progress. Women used to live a life of studentship like the sons were supposed to live.

Women in Upanishad Period: During this period, women of the royal families only enjoyed respect. The status of women continued to be the same as of the Vedic Period.

Women in Epic Period: The status of women with regard to her education was continued during the epic period as well The Ramayana and Mahabharata are resplendent with acts of many good intellect women.

Women in Sutra Period: During this period, the status of women started to decline. A woman was not allowed to possess wealth nor could she have a right to inherit property from her husband.

Women in Buddha Period: In this period, women were admitted to Buddhist order, which means women had an alternative to subjugation to husbands and patriarchy. Women can acquire the property but polygamy existed.

Women in Mughal Period: During this period, women enjoyed greater standard of respect. Educated women were working as lady tutors and some ladies owned colleges as well. The royal ladies enjoyed the privilege of coming with the contact with royal ladies of other countries.

Women in Bhakti Period: This period was a complete setback towards the status of women. It was mainly due to the saint's behavior towards the women. They considered women as object of material consideration.

Women in British Period: The position of women was miserable during this period. The "Sati system" was abolished by Raja Ram Mohan Roy. In the $18^{\text {th }}$ century, the status of women reached to its lowest possible point. In the $19^{\text {th }}$ century, thus the status of women began to elevate in the society.

Women during Freedom Struggle: The freedom struggle boosted the role of the women in the society.

Women in Post-Independence Period: Women were granted complete political, economic, religious and social freedom. They have been granted with right to property, right to education, etc. The status of women in society was better than it was before. Women were moved from their domestic works to public works.

Women in Modern Era: The Department of Women and Child Development (WCD) and other associated bodies were involved in a number of initiatives in order to improve the status of women in the country. The development of women has always been the central focus in developmental planning since Independence. [9]

Women discrimination is to be understood in a more wider sense. There is a need for women to understand the discrimination. They need to be educated for their equal rights in order to avoid such bias. [10]

\section{How Women Discriminate Women in Kashmir}

Women's narrow-minded and gossipy nature is considered to be the reason for the conflict among them. But women were not born pacifists, they do can show strong bond at times of need. During World War I, peace women and defense women united their forces for the sacrifice of the country. [11]Thus, the fact was revealed that women do have extreme in-group bias than men. [12]

The cases mentioned below are of different areas of Srinagar, Kashmir. The work is based on field research.

1. Mehwish, 26 years old is working in one of the reputed companies of Kashmir. She is an elder daughter of her parents and has one sister. She lives at Shalla Kadal with her parents. She described her story how discrimination exists in the same gender. She said, "Being a daughter has become a challenge in her everyday life. Her grandmother used to discriminate her in a number of ways, be it beating for no reason, differential treatment, not allowed to wear clothes of her choice, not allowed to play in the family yard, etc." She further said her grandmother never let her sit at the place where others used to sit especially men. She has received inferior behavior since childhood. And all this was because her grandmother's preference was son's over daughters. She also stated that now she is working but still mocking, ill treatment is going on but not in the way it used to be.

In my understanding, the treatment she is going through is mainly because of the illiteracy factor. Education plays a very important role in molding the society. Her grandmother was illiterate, and grandfather was literate (He never did any sort of acts). Education could have framed a different mind-set for her. We could say this is one of the factors but there can be many such reasons for the same. Inequalities within the 
family needs to be stopped at the earliest.

2. Farzana, 29 years old working in a Government Department of Fisheries. She is an elder sister and has 2 siblings. She lives at Nowgam. She discussed her notion of discrimination by her fellow colleague. She said a girl named XYZ harasses other fellow women. She stated XYZ defames every other girl of their department. She has been ragged by her when she was a new comer to the office. She takes her possessions as such mobile phones, wallet, and other gadgets as well. She is trying to dominate her in every possible manner. XYZ doesn't allow women fellows to communicate with each other.

In my opinion, this is a case of pure jealousy. This is a kind of discrimination existing at the workplace with the same gender. We can eradicate it by proper moral education that can be given to the children at the very young age. Though it is the human tendency to feel insecure but one can overcome it by grooving one's own confidence. In extreme cases, one can approach the harassment cells working in the office premises.

3. Mona (name changed), 21 years old is a single child of her parents. She is pursuing B. A. at Government Women's College, M. A. Road. She lives at Shalla Kadal with her grandmother (Maternal) because her parents are divorced. She said living at her maternal home was never her choice but her helplessness. She told her story of discrimination. She said, her aunt mistreats her she never gets to eat properly, never gets to decide about her future, etc. According to her aunt, Mona is the mistake of her parents and she has to be tamed accordingly so she won't make the same life mistakes. She has been embarrassed by her aunt on several occasions, be it at college, tuition, etc. She is not allowed to have a social life of her own.

To my knowledge, this is Psychological Violence, as she is humiliated, embarrassed, emotionally tortured in order to make her feel deliberately diminished. Although a great boon for her is her grandmother, she has to make family, social relationships better, let others know about the treatment she is going through. Being a human being what we can do is treating each other with honor.

4. Nuzhat, 54 years old women talks about a known topic for discrimination. She is a mother, a housewife having 3 kids. She lives with her husband and kids at Soura. She talked about how a woman discriminates her rights of being a wife. She said a woman was having an extramarital affair with her husband. When she came to know about it, she tried to stop it but the woman was not leaving her husband. Nuzhat is claiming that the woman ruined her marriage life and is enjoying her perks of being a wife without marriage.

This is a case of adultery. We know adultery is the infringement of rights of the wife when done by husband. Though it is no longer a criminal offence in India, but is still considered one of the grounds of divorce. It is considered to be indirectly discriminating against women. [13]

5. Khalida, 50 years old woman residing with her husband at Soura, Srinagar. She is a mother of two girls and works in an NGO. She shared her story which is very common and known to every human being. She told that, she was ill-treated by her mother-in-law and sisterin-law from the beginning of her marriage. She quoted, "Nastikin kaedheam 7 dou" (meaning she was harshly mistreated during the first 7 days of her marriage). She further said, her sister-in-law used to throw the teasheets at her (face) during the early days of her marriage. Her mother-in-law started to taunt her for not bringing in the "required" dowry. All she faced till now was only because of the dowry which she couldn't bring with her. She was further tortured because she gave birth to two daughters and no son.

Therefore, this shows the powerlessness of the daughterin-law's of our society. Culture plays a significant role in governing the relationships of our society.

This study provides the empirical data of how typical the experiences of these women are. It suggests the desire for both quantitative and qualitative research for women discrimination against each other. The research will help to deep dive into such concepts. [14]

There were many instances in my interaction where I came to know about the generous nature of some woman in helping each other. In one case where a person $(\mathrm{H})$ was trying to dominate his colleague (Samreen), being a boss he was trying to torture her to go with him somewhere. But at the same time her colleague came (Ms. Muzamil) to her rescue and took her out from the office premises. Therefore, we can conclude, Women have an inherent right to live their lives free from discrimination. Some of the things that can be done for the women are as under:

1. Supporting women to understand and demand their rights.

2. Encouraging women in their fields, work, life, etc.

3. Providing them legal justice and access of free legal aid.

4. Collaborating with Government to make them aware of their rights. [15]

\section{Conclusion}

Women are prone to discrimination since ages. It is not a new concept, it is something which is present everywhere and even sometimes one can witness in one's own house. The most basic reason is that women don't know their own rights and even don't realize they are being discriminated and it will grow unless there is no awareness.

Women in Kashmir have been subjected to agony since ages. Their status is deteriorated due to many reasons, some of the facts have been illustrated in the Article. The main reasons/ findings of the research work can be summed as:

The large portion of illiteracy rate is one of the reasons for women discrimination in Kashmir. And women acting as sexist is the reason too. Women are unconsciously biased against women. It requires handful of work. 


\section{References}

[1] Sree Krishna Bharadwaj H, "Laws Protecting Women From Gender Discrimination in India - A Critical Analysis" 4 Indian Journal of Research 1 (2015).

[2] Kamala Sankaran and Roopa Madhav, "Gender Equality and Social Dialogue in India" 12 (International Labour Office 2011).

[3] Kelly L. Hazel \& Kerry S. Kleyman, "Gender and sex inequalities: Implications and resistance", 48: 4 Journal of Prevention \& Intervention in the Community 281 (2020).

[4] Combating discrimination against women, available at: https://www.ohchr.org (last visited on March 29, 2021).

[5] Mary Ann Sieghart, "Why are even women biased against women", available at: https://www.bbc.co.uk/programmes/articles/312fXcsr5T1V9p 509XNMYC4/why-are-even-women-biased-against-women (last visited on March 29 2021).

[6] Lelia Gowland, "The Unconscious Bias Women Have Against Women", available at: https://www.forbes.com/sites/leliagowland/2018/06/25/theunconscious-bias-women-have-against-women/amp/ (last visited on March 29 2021).

[7] Sukhpal Kaur, "Women's Rights: A Historical Perspective" 70 The Indian Journal of Political Science 1 (2009).

[8] Alexandra F. Corning, "Self-Esteem as a Moderator Between Perceived Discrimination and Psychological Distress Among Women" 49 Journal of Counseling Psychology 123 (2002).

[9] Dr. B. A. Rani and Bala Theresa Tirumala Reddy, Women @ Empowerment, Education and Emotional Intelligence 18 (Neelkamal Publications Pvt. Ltd., New Delhi, 2013).

[10] Zaiton Othman \& Nooraini Othman, "A Literature Review on Work Discrimination among Women Employees" 11: 4 Asian Social Science 29 (2015).

[11] Drude Dahlerup, "Women against Women" 13: 2 Journal of Women's History 201 (2001).

[12] Laurie A. Rudman and Stephanie A. Goodwin, "Gender Differences in Automatic In-Group Bias" 87: 4 Journal of Personality and Social Psychology 508 (2004).

[13] Soutik Biswas, Adultery no longer a criminal offence in India, Available at: https://www.google.com/amp/s/www.bbc.com/news/amp/worl d-asia-india-45404927 (Last visited on 15 February, 2021).

[14] Jenifer and Joyce, "Perceived Discrimination Among Women in Law Enforcement" 10: 1 Women and Criminal Justice 71 (2008).

[15] "Ending Violence Against Women and Girls", available at: https://www.womankind.org.uk/what-we-do/violence-againstwomen-and-girls/ (last visited on March 29, 2021). 